\title{
STUDYING INSTITUTIONAL ECONOMICS AT CHICAGO IN THE 1930S: THE CASE OF ARTHUR BLOOMFIELD
}

\section{Pier Francesco Asso and Luca Fiorito}

Keywords: Arthur Bloomfield; Frank Knight; Thorstein Veblen; institutionalism; Chicago economics

Arthur Bloomfield (1914-1998) was a fine international economist and an original historian of economics. A native of Montreal, Bloomfield was educated at McGill University, where he studied under Joseph Hemmeon and Stephen Leacock and received his M.A. in 1936. His thesis was on Canadian wheat marketing policy during the Great Depression. Disappointed by the economics he had learned at Montreal, in the fall of 1936 he went to Chicago to begin postgraduate studies. There he studied under the guidance of some of the leading American economists of the age, several of whom would later be identified with the so-called first Chicago School of Economics.

The crucial event that brought Bloomfield to the University of Chicago was a letter from Harry Millis, then the chairman of the Department of

\footnotetext{
Documents Related to John Maynard Keynes, Institutionalism at Chicago \& Frank H. Knight Research in the History of Economic Thought and Methodology, Volume 31B, 57-77 Copyright $($ C) 2013 by Emerald Group Publishing Limited All rights of reproduction in any form reserved ISSN: 0743-4154/doi:10.1108/S0743-4154(2014)00031B003
} 
Economics at Chicago, who encouraged him to enroll in the Ph.D. program and offered him some form of financial support. "Bolstered by that letter," Bloomfield (1994, p. 4) wrote, "I went to Chicago in the fall of 1936, with little money in my pocket but hopeful that somehow or other I would manage to get by." The real scientific motivation for Bloomfield's favoring Chicago was, however, the presence there of another Canadian in the Department of Economics, his future mentor Jacob Viner: "I had read and admired some of his writings and was anxious to meet him and study under him" (Bloomfield, 1994, p. 4).

Bloomfield's hopes and expectations would soon come true. After his arrival at Chicago, Bloomfield took Viner's famous course on price and distribution theory and was offered the opportunity to become his research assistant for his long awaited book, Studies in the Theory of International Trade (1937). Under Viner's influence, Bloomfield soon developed his lifelong interest in international economics and the history of economic thought. A rather unusual choice for the time, his first article in a professional journal was a history of the foreign trade doctrines of the Physiocrats (Bloomfield, 1938), originally written as a term paper for Viner's course.

Under Viner's supervision Bloomfield received his Ph.D. from Chicago in 1942. His doctoral dissertation was devoted to another typical Vinerian issue: the role of capital imports in the structure of American balance of payments. After completion, Bloomfield immediately joined the staff of the Federal Reserve Bank of New York, where he was a senior economist and consultant from 1942 until 1958, when he joined the University of Pennsylvania as a professor of economics. ${ }^{1}$

While at Chicago, Bloomfield devoted time and energies to study the leading figures in American economics, including the institutionalist school. A long essay on Thorstein Veblen was produced as a term paper for Frank Knight's course on "Economics from an Institutional Standpoint." This essay is published here for the first time. ${ }^{2}$

There are several reasons that suggest publication. First, Bloomfield's essay on Veblen provides some evidence on his early works and the way they influenced his scientific career. Remarkable are, in our view, his capacities as a 23-year-old graduate student to produce an original piece on Veblen's analysis of American industrial system and provide convincing arguments on the way he had both deeply influenced American economists and anticipated the real course of events. Second, it is a paper that adds something on our knowledge of what it was like studying economics at the University of Chicago in the 1930s, particularly regarding the requirements of the graduate curriculum. It also provides evidence on 
the role that Frank Knight, together with Viner and other senior economists, played in fostering pluralism in methods and the selection of topics among their most promising graduate students. In this respect, the paper shows how the history of economics and the critical overview of past works played an important part in the making of a junior economist. As Bloomfield recalled, his studies in these topics had a decisive influence in his future career. It was in his early days at Chicago that Bloomfield addressed the perpetual question of the usefulness of history for the making of an economist and acquired a strong personal awareness on its behalf:

The history of economic thought has long been the subject of considerable controversy regarding its usefulness as an academic discipline and as a field for serious study and research. On the one hand it has been denigrated by some economists as of little value and as a kind of waste of time ... on the other hand there are those who insist that the history of economic thought is absolutely essential in the training and continuing education of economists. They argue that no self-respecting economist should lack a reasonably detailed knowledge of the writings of the great economists and schools of thought of the past. I share this point of view. ... most probably it was my interest in international economics rather than in intellectual history as such that prompted me to write these essays. (Bloomfield, 1994, p. 20)

A final, though not minor, reason for publication regards the original insights that can be found in this work regarding the interpretation of Veblen's works. In a comparative way, Bloomfield intertwines a complex network of threads which from Veblen link together some of the most outstanding interpreters of capitalism, including Marx and Keynes, whose General Theory had just been published. The fundamental dichotomy between finance and industry is the guiding principle that leads Bloomfield's reading of Veblen's works. On the whole, then, the paper shows how, as a graduate economics student, Bloomfield had already developed an extraordinary scholarship on economic and methodological matters, as well as a remarkable familiarity with the most recent institutionalist literature on the matter.

The following section introduces the reader to the intellectual environment at the Department of Economics of the University of Chicago, in which institutional economic thought had been a debated topic since the 1910s. In particular, since Bloomfield's paper was conceived as part of the requirements of a course offered by Frank Knight, we have decided to focus particularly on the latter's views on Thorstein Veblen and institutional economics. In the third section of this introductory note, we shall examine in some detail Bloomfield's original interpretation of Veblen. 


\section{KNIGHT, VEBLEN, AND THE HISTORY OF INSTITUTIONALISM AT THE UNIVERSITY OF CHICAGO}

While at Chicago, in addition to Viner, Bloomfield took classes with almost all the leading figures of the "early" Chicago school, such as Frank H. Knight, Oskar Lange, Paul H. Douglas, Theodore O. Yntema, John U. Nef, and Lloyd Mints. ${ }^{3}$ As to Knight, Bloomfield (1994, p. 5) describes him as a "profound scholar," although, he confessed, "[he] was not to me as stimulating a lecturer as Viner." In his Chicago reminiscences Bloomfield asserts that he took "several courses" with Knight, including history of economic thought:

Frank Knight ... made us read from Smith, Ricardo, Malthus, Mill, Marshall and many others; and we were also assigned several of his own articles, especially his famous paper in the 1935 Canadian Journal. All this, plus his learned if at times tedious lectures, were a tremendous improvement on my introduction to the subject at McGill. But my interest in the history of economic thought came mainly from the teaching and writings of Viner. (Bloomfield, 1994, p. 17)

However, Bloomfield provides no information about Knight's course on "Economics from an Institutional Standpoint," numbered Economics 305. From evidences retraced by Malcolm Rutherford (2010, p. 32), we learn that Knight taught that course from 1932 to at least 1942, although the course was not offered with continuity. In a 1937 letter to his friend and institutionalist "rival" Clarence Ayres, Knight himself offers a rather telling (and provocative) description of the aim and contents of the course. The letter reveals the little value that Knight attached to the constructive side of the institutionalist doctrine, particularly as an instrument to understand real economic events:

You probably know that I attempt to give a course on "Economics from an Institutional Standpoint." I am taking the liberty of inflicting on you my latest outline and reading list. I would very much appreciate critical comments, and especially suggestions of good short reading. ... It is unnecessary to say that I don't place any very high estimate on the constructive value of institutionalist writings as known to me - including those of C. E. Ayres! What I would like to do would be to take the "challenge" seriously and make some real contribution toward an understanding of institutional development. In this connection, I am convinced that legal philosophy and legal history form the main item which needs emphasis, with religion probably in second place. (Knight to Clarence E. Ayres, 16 February 1937; quoted in Samuels, 1977, p. 305) 
In the same letter Knight included the following outline for Economics 305, to be taught in Winter 1937 (which makes this most likely the version of the course that was actually taken by Bloomfield):

I. The Institutionalist Movement.

II. The Historical Schools of Economic Thought.

III. General Problems; Institutions, their Origin and Development.

1. The Meaning of Institutions.

2. Process and Causality in Institutional Change (in addition to above).

IV. The Institutional View of Economic Life. The task of institutionalism that of accounting historically for the factors treated as data in rationalistic, price-theory economics.

1. The economic attitude; individualism and utilitarianism.

2. Wants.

3. Technology.

4. Resources.

5. Organization.

6. Economic Institutions as Embodied in Law.

(Knight to Clarence E. Ayres, 16 February 1937; quoted in Samuels, 1977, p. 305$)$. $^{4}$

Albeit incomplete and fragmentary, this list of topics reveals that Knight had a deep understanding of the several dimensions of institutionalism. Although the bulk of the readings for the course dealt with institutionalist writers as they were properly understood - such as Veblen, Wesley C. Mitchell, John R. Commons, John Maurice Clark, Walton H. Hamilton, and others - his knowledge of the literature encompassed both U.S. and European sources. What is also interesting is that Knight conceived institutionalism as including German Historismus and the analysis of religious beliefs, as determinants of the prevalent socio-economic philosophy of life, provided by Werner Sombart, Max Weber, and Richard Tawney (Samuels, 2005, p. 144).

Knight's keen interest in institutionalism, broadly conceived, appears to be in line with his earlier methodological commitments. In 1924, writing for Rexford G. Tugwell's celebrated volume on The Trend of Economics, he had distinguished between three distinct and equally necessary "methods of treatment" in economics. The first is "economic theory in the recognized sense," which Knight mainly identified with marginalism and defined as 
"a study, largely deductive in character, of the more general aspects of economic cause and effect, those tendencies of a price system which are independent of the specific wants, technology, and resources" (Knight, 1935 [1924], p. 144). The second method is "applied economics," which "should attempt a statistical and inductive study of the actual data at the particular place and time, and of the manner in which general laws are modified by special and accidental circumstances of all sorts" (Knight, 1935[1924], p. 144). Finally, the third division of economics is

\footnotetext{
the philosophy of history in the economic field, or what some of his votaries have chosen to call "historical" and other "institutional" economics, studying the "cumulative changes of institutions." Insofar as it aspires to practical utility it will endeavor to predict long-period changes in the factors which applied economics accepts as data and attempts to observe and use as bases of inference. As far as can be seen now, this third division, even more than the second, is a field for the exercise of informed judgment rather than for reasoning according to the canons of science. The movements of history are to be "sensed" rather than plotted and projected into the future. (Knight, 1935 [1924], p. 144)
}

As we have argued elsewhere (Asso \& Fiorito, 2007), Knight's own version of institutionalism differed both in its methodological and epistemic foundations from the one advocated by the leading institutionalists of the time. What concerns us here is that he saw American interwar institutionalism as epitomizing the pernicious alliance between the "social control" approach to social policy, positivistic scientism, and Deweyan pragmatism that emerged out of the American intellectual arena during the first two decades of the last century (Fiorito, 2009, 2011). Although Knight's favorite target for criticism was the so-called "scientific" wing of the movement, represented by younger figures such as Morris A. Copeland and Lawrence K. Frank, he was by no means more generous with Veblen. He had in fact firmly rejected the instinct-habit psychology on which Veblen's evolutionary program was based (Asso \& Fiorito, 2004), thus showing little consideration for the heuristic value of his fundamental dichotomy: in his opinion "the most serious defect of the Veblenian philosophy comes out in the contrast between pecuniary and industrial employments, of which so much is made" (Knight, 1920, p. 519). ${ }^{5}$ Specifically, he held that the Veblenian notion of a dichotomy between industry and business rested on an "obvious fallacy," namely, the idea that "society has a choice between producing more goods and producing more value, and that it is the part of wisdom to prefer the former." According to Knight, Veblen's dichotomy was intrinsically normative and missed the centrality of the value problem 
implied in every economic - i.e., instrumentally rational - decision. ${ }^{6}$ As he put it:

The quantity of goods, if there is more than one kind, must so obviously be measured in value units. The proposal of leaving it to technicians in the respective fields to say how much social productive power shall be expended in each is merely grotesque; military experts would use it all for the army and navy, the medical men could usefully employ it all, and more, for health, and so on. There is no more important function of a first course in economics than to make the student see that the whole problem of social management is a value problem; that mechanical or technical efficiency is a meaningless combination of words. (Knight, 1923, p. 582)

It should be noted that Knight did not deny - to some extent following Veblen - the problems arising from the separation between property and control that was beginning to characterize the real nature of the American corporation. "Those in control of the policies of a business," he wrote in Risk, Uncertainty and Profit (1921, p. 333), "are almost inevitably in a better position to foresee its future earnings than are outsiders, and it is difficult to prevent their taking advantage of this position to the detriment of their efficiency as managers of productive operations." Such a situation becomes even worse when

the managers of productive property begin to manipulate their industrial and financial policies with a view to producing changes in capital values, of which they inevitably know in advance of outsiders and of which they take advantage with corresponding ease. Instances of such action with enormous gains reaped by insiders are familiar to all who know anything of modern corporation history. It is hard to see how they can be prevented without a strengthening of the moral code of business and a strict application of criminal law. (Knight, 1921, p. 334)

Thus, Knight was willing to concede that "this form of business activity ... perhaps it had been neglected unduly by economists," but, he immediately added: "Veblen's allegation that such stealing through the production of disturbances in business arrangements is the usual or characteristic activity of modern economic life is of course merely humorous" (Knight, 1921, p. 334 n1). And in a letter to Joseph Dorfman he sarcastically added:

I would really like to know what standing Veblen has or had, if any, in the field of Archaeology, which is the foundation of his whole position. I have never happened to know of any recognized archaeologist recognizing Veblen's existence. If I am grossly uninformed in that connection, I do wish you would give me references which would enable me to get right. Another question which is, of course, impertinent to ask, but about which I was even more puzzled, was whether your statement about Veblen's standing among "the economists who count" was meant seriously, or was intended to be funny. (Knight to Dorfman, December 18, 1940; quoted in Fiorito, 2007) 
In spite of this (sometimes extremely harshly) critical stance which regarded both its methodology and the building up of a new paradigm, it remains true that Knight took institutionalism quite seriously and, more significantly, considered it as an essential part of the "making of an economist" at Chicago. This is confirmed not only by the large portion of his Economics 305 course devoted to the discussion of the movement (Samuels, 2005), but also by the fact that he regularly included questions on American institutionalism and its leading advocates in the Ph.D. qualifying exams on Economic Theory at the University of Chicago. As documented by Fiorito (2012), aside issues of pure theory, Ph.D. candidates in economics at Chicago were in fact requested to prove a specific acquaintance with institutionalism and its basic philosophical postulates. What follows are all questions with an explicit institutionalist content that are found in the qualifying exams during the 1930s. Significantly, the first question is dated 1932, the very year that Knight began to teach his Economics 305 course:

(1932 spring) Discuss the relationship between the conclusions and assumptions of the neo-classical school, the Weber-Sombart school and the American institutionalists.

(1932 summer) Summarize and appraise the contribution of Veblen to economic thought.

(1932 autumn) Briefly state your conception of the nature of institutional economics, its relation to the price-type theory type of economics and its value to the student. Comment on the work of Adam Smith, J.S. Mill and Alfred Marshall with regard to the adequacy of the consideration given by them to institutional factors, and discuss the desirability of replacing the standpoint of Marshall by that of any institutionalist or group of institutionalists.

(1933 autumn) Briefly characterize and evaluate comparatively what you consider the significant "approaches" or methodologies in economic science. (The following are to be taken as suggestive catch-words: classical, inductive, institutional, deductive, pricetheory, sociological, socialistic, control.) Where possible, cite examples of the different tendencies in the history of economic thought from the Greeks to the present.

(1935 autumn) Indicate briefly the position of the institutional school of economists in America. With what earlier movements in the history of doctrine could it be compared, giving illustrative names in both cases.

(1937 summer) Sketch the relation between the economic doctrines of Marx and Veblen, relating both positions to the problem of an "institutional economics" and to the writings generally representative of this position.

\section{BLOOMFIELD ON VEBLEN}

Given the above, therefore, it is not surprising that some - plausibly not a few - of Knight's students decided (or were requested) to write a term 
paper on some institutionalism-related themes. Along with the Bloomfield's paper reproduced here, Rutherford (2011, p. 32) points out that Kenneth Parson's article on "John R. Commons' Point of View" (Parsons, 1942) also originated as a term paper for Knight's Economics 305 course. In terms of the candidacy exam questions identified above, Bloomfield's paper addresses at least two of them: the contributions of Veblen and the comparison of Veblen with Marx.

In his introductory remarks Bloomfield was wary enough to make no special claim of "originality" in his interpretation of Veblen, "although I believe that I have brought together in this essay the results of a certain amount of reading and thought, which I hope may cast a little bit of additional light on Veblen's work." Indeed, the paper offers a clear presentation of Veblen's methodological critique of neoclassical economics and shows how this could be combined with his evolutionary approach for a better understanding of the American industrial system, characterized as it was by distortions, abuses, and inefficiencies. Essentially Bloomfield - who himself had Eastern European grandparents - follows Dorfman in recalling how Veblen's origins played a great part in his attacks against the American Captains of Industry and in designing a fundamental clash between the real production of goods and the effortless and damaging behavior of the financing and business class. Apart from these considerations there are several interesting and suggestive insights that may be found in Bloomfield's critical scrutiny of Veblen's works. The following are a few illustrative examples.

\section{The Fundamental Dichotomy Revisited}

Bloomfield's paper focuses mainly, albeit not exclusively, on Veblen's wellknown dichotomy between industrial and pecuniary pursuits. Significantly, as we have seen before, this was the aspect of Veblen's thought that had attracted Knight's major criticisms. "Briefly stated," Bloomfield writes:

The general idea is that whereas considerations of serviceability and general social welfare demand the maximum production of wealth at the lowest price, considerations of 'vendibility' and business expediency demand rather a restriction of production, a 'conscientious withdrawal of efficiency' and all manner of disserviceable and predatory activities, with the result that the economic system is in a continual state of underproduction, booms, and depression.

Accordingly, Bloomfield explains, for Veblen the industrial system is governed by the physical laws that determine the technological process and the 
technical constraints on the potential production and distribution of goods. Conversely the pecuniary system around which business activities are organized is the result of our social institutions: the conception and legal articulation of private property, commercial laws and customs, and financial contracts. Throughout the paper Bloomfield develops some critical analysis of Veblen's dichotomic schema. From the outset, however, he makes clear that Veblen's system of thought is tainted by an "overwhelming stress and emphasis on the technological." As he put it:

\footnotetext{
Veblen had what might be termed a "technological bias." He was one of the first to understand and realize the significance of the great change that had taken place in the "state of the industrial arts" in America. The effect of the new age of power and machinery on men's habits, ideals and outlooks is clearly stated. The technological bias colored his thought and analysis at every turn, and accounts for many of the rather unusual conclusions at which he arrived. For example, this accounts for his idea that the real productive classes in the community, and the symbol of productive efficiency are the engineers, the technicians and the industrial experts, and not the proletariat, as with Marx. It also explains the rather curious conclusion that these men are to be the ones who will effect the "revolutionary overturn" and control the destinies of the reconstructed society.
}

Such a technological bias, Bloomfield insists, also explains the "rather curious conclusion" that the engineers are to be "the ones who will effect the 'revolutionary overturn' and control the destinies of the reconstructed society." This specific criticism will be taken up below.

\section{Veblen and His Contemporaries on the Constructive Side of Institutional Economics}

This critical premise notwithstanding, Bloomfield recognizes the constructive nature of Veblen's contribution and finds some important parallels between his analysis of business enterprise and that advanced by other leading writers of the time. For instance, Bloomfield argues that Veblen's discussion of non-perfectly competitive markets "foreshadowed much of the important work subsequently done by Chamberlin, Sraffa, Joan Robinson, Zeuthen, Harrod, Stackelber and others." In particular, Veblen intuitively recognized that all industrial enterprises - at some stage or another - reap advantages from a more or less significant degree of monopolistic power which is a major cause for production cuts, predatory activities and other forms of "conscientious withdrawal of efficiency." Specific attitudes toward monopolistic power were again reinforced by the 
dichotomic nature of capitalism, as they are basically derived from different sorts of all intangible assets which constitute business capital. Thus, the increasingly complex network of immaterial relations on which the modern firm was based - so Veblen argued - tended to produce no aggregate advantage to the community as a whole, though they became a decisive element of cumulative crisis and cyclical collapse of aggregate production.

In a similar fashion, Bloomfield asserts that "in much of his analysis of the modern corporation and in the sharp separation of ownership and control, multiple capitalization, etc. Veblen foreshadowed much of the work subsequently done by Berle and Means, and incidentally in the work of these latter men, Veblen's conclusions are largely supported." Interestingly, when dealing with Veblen's $(1921$, p. 8) contention that "any country that is organized on the price system ... habitual unemployment of the available industrial plant and workmen in whole or in part, appears to be the indispensable condition without which tolerable conditions of life cannot be maintained," Bloomfield finds it "remarkably similar to the conclusions arrived at, by a more circuitous and a priori route, by Mr. Keynes." Bloomfield's knowledge of Keynes' work dated back at McGill University where in the fall of 1936 he was asked to give a seminar in the Hemmeon class on the just appeared General Theory, revealing, however, that his instructor had provided "little or no guidance in understanding it." What is significant here is that at Chicago Bloomfield developed a capacity to find similarities between Veblen and Keynes's conceptions of "underemployment equilibrium": an affinity that in the academic literature would only be pointed out 2 years later by Rutledge Vining (1939) in his famous article on "Suggestions of Keynes in the Writings of Veblen."

As far as Veblen's direct influence on his contemporaries is concerned, however, Bloomfield's main target was Herbert J. Davenport. According to Bloomfield, Veblen's dichotomy between industrial and pecuniary employments was reflected in Davenport's distinction between "business" and "industrial" capital. As he explained:

In fact, the general thesis of his Economics of Enterprise (1913) is that individual gain does not necessarily coincide with social welfare, and that capital in possession of the individual need not correspond with wealth as a substantial resource in the community. He thus clearly distinguishes capital as a pecuniary, acquisitive concept and as a productive concept. All through his works runs the central idea that valuation in terms of private capital does not necessarily reflect production in the social sense. The predatory aspect of capital is summed up in his words to the effect that "a great part of the 120 billions of American wealth ... is made up of one form or another of capitalized privilege or of capitalized production" (1913, p. 519). In fact, as he continues, "two-thirds of the durable private bases of income in the United States are nothing else than the 
capitalization of privilege or predation. The market value of these non-social or antisocial forms of private capital is merely the present worth of the right to exact tribute from one's fellows or to plunder one's fellows" (1913, p. 529). He lays much stress on "unearned income" (corresponding to the "free income" of Veblen's "absentee owners") and traces it to three chief sources: (1) capitalized bounty of nature (rent, etc.); (2) capitalized predation (restriction of output, deterioration of products, etc.); (3) capitalized privilege (franchises etc.). The trouble with economists, contends Davenport, is that they have "assumed that private gain and social welfare are approximately interchangeable concepts ... (they) have failed to recognize that some of the capital is as iniquitous and disastrous for social welfare as some of the capital is beneficent" (1913, p. 519). The parallelism here to Veblen is so obvious as to preclude the need for any further comment.

Bloomfield's appraisal of Davenport along Veblenian lines shows the clear influence of Knight - who had spoken of Davenport's "almost fervent admiration for Veblenism" (Knight, 1931, p. 9) - and appears to be in contrast with recent attempts to assess Davenport along strictly Austrian lines (Gunning, 1998).

\section{Veblen on the Future of Capitalism}

Following Knight, Bloomfield's analysis becomes more unsympathetic when he goes on to examine Veblen's views concerning the future of capitalism. According to Bloomfield, in The Theory of Business Enterprise, Veblen (1904) saw two possible future scenarios emerging out of this inherent conflict between business and industry. The first would be "a reversion to the ancient dynastic state, based on a Romantic philosophy, with stress on ceremonial, pageantry, graded dignity, allegiance, piety, servility and war" - a situation that Bloomfield found epitomized by the then current authoritarian regimes in Italy and Germany. The second scenario would imply a "revolutionary overturn," establishing a "system based on considerations of serviceability and human welfare" - a possibility toward which Veblen had become much more skeptical in his later works. If a revolution were ever to come about in America, however, Veblen believed it would occur through the establishment of a "Soviet of Technicians." "It was here" - Bloomfield notes - "that Veblen placed all his faith in the engineers, technicians and industrial experts" and that his "technological bias" becomes more evident. If such a Soviet of Technicians should acquire control over the whole industrial system, Veblen argued, its motivations would be to provide a more efficient management of the community material welfare. It would correct the deficiencies of management by businessmen and 
concentrate its powers on those areas of industrial administration where the business system has most conspicuously failed. As for the revolutionary overturn itself, there need be neither violence nor mass demonstration - all that would be necessary would be a "general strike" of the country's technicians, bringing industry to a standstill. The absentee owners would then either abdicate or be dispossessed by a legal order cancelling all corporation securities.

Bloomfield raises two distinct objections to Veblen's revolutionary scheme. First, he points out the utopian - "naive" in his words - nature of Veblen's reasoning. Ruling classes do not give up their privileges on request, nor there appeared to be any reason why engineers as a class should be immune from the pecuniary logic of the vested interest. As Bloomfield explained:

In the first place, Veblen appears excessively naïve in his belief that the revolutionary overturn could be achieved by a mere strike on the part of the engineers. Long before anything like that happened, either the engineers would be "bought off" or a Fascist regime would be set up. To think that the capitalist class would idly sit by and allow their Vested Interests to be expropriated, is to completely misapprehend their strength, and completely misread recent European history. Thus although Veblen may have been a radical subjectively, he was a Fascist objectively.

However pertinent Bloomfield's remarks in this connection may be, he neglects to acknowledge that Veblen was always careful to qualify his speculations with the disclaimer that the engineers themselves "are a scattering lot of fairly contented subalterns, working piecemeal under orders from the deputies of the absentee owners," while "the working force of the great mechanical industries ... are still nearly out of touch and out of sympathy with the technical men, and are bound in rival trade organizations whose sole and self-seeking interest converges on the full dinner-pail" (Veblen, 1921, p. 104).

Second, Bloomfield held that "Veblen's views on the future society are woefully inadequate, and leave out some vital issues." In Bloomfield's eyes, only the market system and the price mechanism are capable of objectively measuring the efficient allocation of resources:

Veblen believed that all that was necessary was for the Soviet of Technicians to take control; the rest would be easy. Veblen falls into this trap by his same technological bias. To him, the problem of the new society would be an engineering one entirely, or at least almost entirely. To him it would merely be a matter of allocating resources among the primary industries, and to produce the maximum possible under the existing technological conditions, with the minimum of waste and inefficiency. To him the problems of economic organization were largely technical and engineering ones. But such 
fundamental problems (problems of collectivist society would also have to meet) as the proper and "rational" allocation of resources among alternative uses, the position of free consumers' choice, the method of distribution and the criteria to be followed, economic incentives, the relation between the "controllers" and the "controllees" - these, and many other fundamental problems which any economic society would have to meet, are all completely neglected - Veblen has nothing to say of them. Not that these problems are entirely insoluble, but the fact remains that they are entirely overlooked in the analysis. Veblen's concept of social welfare was solely that of the maximum production of goods and services at the least cost; he naively believed that such could be achieved merely by disallowing Absentee Ownership and putting engineers and technicians in control. The real problem of social welfare involves much more than merely that. The whole question of distribution is fundamental.

Here Bloomfield follows Knight in interpreting Veblen as advocating a complete displacement of the "price system" and a substitution of technological value for value as measured by market price. Bloomfield focuses on The Engineers and the Price System (1921) as this was representative of Veblen's thought or, at least, exemplified important tendencies in it. Actually, the relation of The Engineers and the Price System to Veblen's earlier contributions has been the source of some controversy. While Donald Stabile (1984, p. 15), on the basis of this work, sees Veblen as one of the inspiring sources of the Technocratic movement and argues that "Veblen was the chief ideologue of the New Class of coordinators," Rick Tilman (1996, p. 177) affirms that the position sketched there by Veblen can best be viewed as "an expository device expressing satirical intent, not as a serious plan for economic reconstruction." Bloomfield, who points out "the remarkable parallelism between Veblen's conclusions and those of the Technocrats," clearly sides with Stabile's interpretation.

\section{Veblen and Marx}

What was Bloomfield's final verdict on Veblen's theory of business enterprise? Interestingly, although Bloomfield had developed his analysis of Veblen in somewhat critical terms, his overall judgment appears to be definitely more favorable than Knight's. Unlike his teacher, in fact, Bloomfield has no hesitation in expressing his own personal agreement with Veblen's condemnation of the parasitical function of much of the business community:

It happens to be my own personal point of view (whatever that may be worth) that Veblen's general conclusions as to the nature of Business Enterprise are substantially true. Our system is not producing as much as it could, and frankly, I do not hold out a 


\begin{abstract}
great deal of hope that much improvement can be expected, least of all by any "positive program of laissez-faire." One of the most serious problems facing America today is that of underproduction, the existence of which can be largely if not entirely traced to the fact that making goods is subordinated to the making of money. I do believe that many of the activities of our business leaders, especially those in strategic positions, are definitely of an anti-social nature, and that the wage-earner and the consumer are the direct sufferers. Anyone who examines the literature of corporation finance and the reports of Industrial Commissions will find ample information to support these contentions. Nor do I hold out great hopes for a rectification of these abuses, but look on them rather as the inevitable result of the present system. The same conclusions apply to monopoly and tariffs. I do believe that there is much truth to the "contradictions of capitalism" of which Veblen wrote, and that though capitalism has made remarkable advances, we should always remember that the real criterion of its success is not what it has done, but what it could have done under the existing state of industrial arts.
\end{abstract}

On the other hand, Bloomfield followed Knight in arguing that Veblen offers no viable alternative to private ownership and control of the means of production and use of the existing market mechanism:

Where Veblen fell down was that although he clearly elaborated on the abuses and inefficiency of capitalism, he did not offer a workable alternative. He thought that a society directed by engineers would be the solution to the problem. But as I pointed out before, the problem is not as simple as all that. Even the method he proposed whereby his reconstructed society could be achieved is clearly inadequate, and excessively naïve.

"It appears to me," Bloomfield concluded, "that Marx was much more logical and realistic on this score." Indeed, the reference to Marx is not incidental. Bloomfield devotes in fact the end of his paper to a brief digression "on the relation of Veblen to Marx, whom he closely resembles." "The more I read of Veblen," he insists, "the stronger does this resemblance become." While Bloomfield concedes that there are some fundamental differences between the two thinkers, he believes them to be at the periphery and not at the core of their analyses of the capitalistic process: "The chief points of major difference are really few." As to their philosophies of history, whereas Marx adhered to the preconceptions of teleological formulations, Veblen questioned the assumption that there are institutional tendencies that can be predicted with the certainty of the natural sciences. While Marx believed in a direct connection between the poverty and oppression of the working class and their collective impulse to challenge the power structure of capitalism, Veblen "objected to Marx's concept of 'conscious' human nature" and "demanded a more 'realistic' psychology."

As far as their theories of business enterprise are concerned, Bloomfield continues, "the chief difference lies, I think, in their concepts of capitalistic 'exploitation." On the one hand, Marx emphasized the exploitation of the 
working class through the capitalist class's control of the means of production while his analysis proceeds from his own labor theory of value: "For labor is the source of all value; the capitalist appropriates a substantial portion of this by buying labor-power at one price and selling labor at another; ergo, the laborer is exploited of the fruits of his labor." On the other hand, Veblen rejected the labor theory of value and emphasized the exploitation of the underlying population through the control of the market system by big business. The difference in perspective is well explained by Bloomfield:

\begin{abstract}
According to Veblen the labor theory of value was all wrong. "Exploitation" under his scheme took the following shape: the community is not getting the volume and quality of goods and services which it deserves. There is a capitalistic sabotage - production is held back, and the underlying population is being deprived of the fruits of the advance in the state of the arts; the usufruct of what is the common property of the community at large has fallen into the hands of a small group. The question of "distribution" in the Marxian sense is not discussed at all. Veblen is not interested in whether the capitalist class is extorting a surplus-value from the laboring class. He is interested in the fact that the laboring class is being bereft of what the advance in the state of the arts could logically furnish them, due to restriction of production, and other waste or inefficiency characterizing a capitalist economy.
\end{abstract}

In spite of these differences, however, Bloomfield asserts that "Veblen comes very close to Marx in analysis." To Bloomfield, Veblen's notion of "free income" - that is, income derived from intangible assets rather than a return from productivity - shows a clear resemblance to Marx's "surplus value," while Veblen's open condemnation of absentee ownership seems to suggest that he "had in mind something approaching a labor theory of value." All this led Bloomfield to reiterate his belief that "the two writers are closer in analysis, if not in conclusions, than is commonly assumed." 8

\title{
FINAL REMARKS
}

At the end of this brief note there is still one crucial aspect that we have left unexplored. Why did Knight, in spite of his outspoken critical stance to institutionalism, expect his students to devote so much time to reading works by American institutionalists and to write research papers on institutionalist themes? In venturing an explanation for this apparent paradox, we must first remember that in the mid-1930s institutionalism was by no means a dying force in American economics. ${ }^{9}$ This was true especially in terms of the discipline's impact on American economic policy. While the 
Keynesian revolution was still in the making, both within and outside academia, institutionalists such as Rexford Tugwell, Walton H. Hamilton, Gardner Means, John Maurice Clark, Isador Lubin, and Mordecai Ezekiel had made important contributions to the conception and implementation of the New Deal reformist agenda (Barber, 1996). Incidentally, in his essay Bloomfield ably detects Veblen's influence on a then popular writer like Stuart Chase - who allegedly inspired the expression "a New Deal" (Vangermeersch, 2005).

Just as important, interwar neoclassicism in America was a contested terrain (Morgan \& Rutherford, 1998). In this connection, a couple of years before Bloomfield arrived in Chicago, Knight (1934a, 1934b) had not hesitated to firmly distance himself from Robbins's seminal effort to define economics as the rational allocation of scarce means among competing and unlimited ends. Specifically, Knight was bothered by Robbins' attempt to characterize economics as a positive science and by his exclusive emphasis on the notion of material scarcity. ${ }^{10}$ In a strikingly Veblenian fashion, Knight wrote in 1936 that "the real scarcity which seriously afflicts individualistic civilization is the scarcity of such things as distinction, spectacular achievements, honor, victory, and power - which is clearly not to be cured by any application of scientific technique" (Knight, 1936, p. 234). One of Robbins' goals was to expunge from the realm of scientific economics any vestige of institutionalism and historicism (Howson, 2004), and yet here was his friend Knight attending to what Robbins wished to expunge. Given the above, then, we cannot but conclude by referring to Warren Samuels, who advances three possible explanations for Knight's teaching a course on institutionalism:

First, he was bothered by institutionalism; he thought the institutionalists were not only wrong in what they said and tried to do, they were dangerous to society and to economics. Second, he appreciated that unlike the professional work of most neoclassicists, the work of the institutionalists dealt with important questions. Third, he appreciated that many things taken as given, or unexamined, by neoclassical economics were actually in a process of evolution - one of institutionalism's important claim. (Samuels, 2005 , pp. 150,151$)$

\section{NOTES}

1. From 1949 to 1950, while at the New York Fed, Bloomfield served as a financial adviser to the Bank of Korea, helping to create the foundation of the country's central bank. He later served as a financial adviser to the Korean Ministry of Finance and the United Nations Korean Reconstruction Agency (Alacevich \& Asso, 2009). 
2. Arthur I. Bloomfield's essay “Thorstein Veblen and His Analysis of Business Enterprise" is published here for the first time, as far as the present editors can determine. The typewritten manuscript was found among the Bloomfield's papers at the Rubenstein Rare Book and Manuscript Library of Duke University and is reproduced with its permission at the end of this introduction. In editing the manuscript no major problem arose: minor errors in spelling and punctuation have been corrected, while full references to the sources cited by Bloomfield in the text have been provided and arranged according to contemporary standards.

3. In this connection, Bloomfield (1992, p. 2058) recalls: "When I was at Chicago I never heard of, nor suspected the existence of, a 'Chicago School' of economics. On the contrary, I was then impressed by the diversity of thinking and interests of the individual faculty members." On the pluralistic nature of US interwar economics see the classic contribution by Morgan and Rutherford (1998).

4. Student's notes from Knight's Economics 305 for the academic year 1933-1934, including a complete syllabus, are reproduced in Samuels (2005).

5. By contrast, it should be pointed out that Knight (1935) phrased his review of Commons' Institutional Economics (1934) in mildly sympathetic terms.

6. This is by no means to imply that Knight did not acknowledge the limitations of instrumental rationality when dealing with his own version of institutionalism. In this connection, despite their different philosophies, there are important points of convergence between Veblen and Knight. See the discussion in Asso and Fiorito (2007), Hodgson (2004), and Tilman (1992).

7. Bloomfield's reference here is to Henry Simons' famous pamphlet A Positive Program for Laissez-Faire: Some Proposal for a Liberal Economic Policy. Simon was an outspoken critic of New Deal economic programs, most particularly, as pointed out by William J. Barber (1996, p. 90), of those associated to institutionalists like Tugwell. In his pamphlet, Simons (1948[1934], pp. 41, 42) affirmed that "the real enemies of liberty in this country are the naive advocates of managed economy or national planning," and made a plea for a return to the founding principles of "nineteenth century liberalism" which had been "subjected latterly to gross misinterpretation and to shallow satirical jibes in the "new economics." Bloomfield (1994, p. 6) recalls in his reminiscences:

\footnotetext{
I never took a course with Henry Simons, the exponent of the 'positive program for laissez-faire' and along with Knight, regarded today as a member of the early 'Chicago school.' But I did have several stimulating conversations with him. ... [However] it was from Douglas and Viner that I learned the importance of knowing the real world and real-world problems before attempting to apply abstract economic theory to reality, especially when offering policy recommendations.
}

8. The Marx-Veblen relationship was a debated issue in the literature of the period. While an early interpreter such as Richard V. Teggart had pointed out the Marxian character of Veblen's analysis of capitalism, Abraham L. Harris contended that "it is only in broad outline that their works can be held to be similar." According to Harris (1934a, p. 840: see also Harris, 1934b):

Veblen, like Marx, viewed economic society from the standpoint of change and posited economic factors as the motivating forces of change. He did not subscribe, however, to 
Marx's historical materialism as the author seems to think. The mechanics through which Veblen's economic factors take their effect upon human consciousness and the course of history are the conflicting habits of occupational discipline rather than the dialectics of class struggle. If the author had seen this difference and had carried the analysis of it far enough he would have found a more satisfactory explanation of why Veblen's dissent remained purely intellectual and Marx's created a popular movement.

9. In 1938 Albert B. Wolfe wrote to Wesley C. Mitchell: "It just happens that in our department here [University of Ohio] with forty members, we have some dyed-in-the-wool mathematical equilibriumists and also a number of men who are convinced that deductive economics is futile and that the only fruitful point of view is institutionalism" (Wolfe to Mitchell, October 26, 1938; quoted in Fiorito, 2000, p. 269).

10. As Knight put it in his personal correspondence with Robbins: "I am inclined to think that the fundamental judgment stressed so much in your book, of an absolute contrast between judgments of facts and judgments of value, is actually the basic error in the theory of nineteenth century liberalism. Stating it another way, I am inclined squarely to reverse the maxim De gustibus non disputandum, in this regard, and hold that only judgments of value can be discussed, facts as such not at all. That is, when we disagree about a fact it seems to me we disagree about the validity of observation or evidence, and that every disagreement is essentially a difference in evaluation" (Knight to Robbins, February 17, 1934; quoted in Asso and Fiorito, 2007).

\section{ACKNOWLEDGMENTS}

We would like to express our gratitude to Elizabeth Dunn, Research Services Librarian at the Rubenstein Rare Book and Manuscript Library of Duke University, for her invaluable help during our research, and to Sebastiano Nerozzi and Ross Emmett for their comments on a previous draft of this introduction.

\section{REFERENCES}

Alacevich, M., \& Asso, P. F. (2009). Money doctoring after World War II: Arthur I. Bloomfield and the Federal Reserve missions to South Korea. History of Political Economy, 41(2), 249-70.

Asso, P. F., \& Fiorito, L. (2004). Human nature and economic institutions: Instinct psychology, behaviorism, and the evolution of American institutionalism. Journal of the History of Economic Thought, 26(4), 445-77.

Asso, P. F., \& Fiorito, L. (2007). Was frank knight an institutionalist?. Review of Political Economy, 20(1), 59-77. 
Barber, W. J. (1996). Designs within disorder: Franklin D. Roosevelt, the economists, and the shaping of American economic policy, 1933-1945. Cambridge: Cambridge University Press.

Bloomfield, A. I. (1938). The foreign-trade doctrines of the physiocrats. American Economic Review, 28(4), 716-35.

Bloomfield, A. I. (1992). On the centenary of Jacob Viner's birth: A retrospective view of the man and his work. Journal of Economic Literature, 30(4), 2052-85.

Bloomfield, A. I. (1994). Essays in the history of international trade theory. Cheltenham, UK: Edward Elgar.

Fiorito, L. (2000). The years of high pluralism: US interwar economics: New light from the Wesley C. Mitchell correspondence. Research in the History of Economic Thought and Methodology, 18C, 267-338.

Fiorito, L. (2007). Frank knight on Thorstein Veblen: A divertissement. Storia del Pensiero Economico, 4(2), 213-14.

Fiorito, L. (2009). Frank Knight, John Dewey and American institutionalism: A note. European Journal of the History of Economic Thought, 16(3), 475-87.

Fiorito, L. (2011). Frank Knight, John Dewey, and American pragmatism: A further note. Research in the History of Economic Thought and Methodology, 29A, 59-72.

Fiorito, L. (2012). American institutionalism at Chicago: A documentary note. European Journal of the History of Economic Thought, 19(5), 829-36.

Gunning, P. J. (1998). Herbert J. Davenport's transformation of the Austrian theory of value and cost. In M. Rutherford (Ed.), The Economic Mind in America: Essays in the History of American Economics (pp. 99-127). London: Routledge.

Harris, A. L. (1934a). Review of Thorstein Veblen: A chapter in American Economic thought, by R. V. Teggart. Journal of Political Economy, 42(6), 838-40.

Harris, A. L. (1934b). Economic evolution: Dialectical and Darwinian. Journal of Political Economy, 42(1), 34-79.

Hodgson, G. M. (2004). The evolution of institutional economics: Agency, structure, and Darwinism in American institutionalism. London: Routledge.

Howson, S. (2004). The origins of Lionel Robbins's essay on the nature and significance of economic science. History of Political Economy, 36(3), 413-43.

Knight, F. H. (1920). Review of the place of science in modern civilization, by T. Veblen. Journal of Political Economy, 28(6), 518-20.

Knight, F. H. (1921). Risk, uncertainty and profit. New York, NY: Houghton Mifflin.

Knight, F. H. (1923). The ethics of competition. Quarterly Journal of Economics, 37(4), 579-624.

Knight, F. H. (1924). The limitations of scientific method in economics, in The ethics of competition and other essays (pp. 105-47). New York, NY: Harper, 1935.

Knight, F. H. (1931). Davenport, Herbert Joseph. In E. R. A. Seligman \& A. S. Johnson (Eds.), Encyclopaedia of the social sciences (Vol. 5, pp. 8-9). New York, NY: Macmillan.

Knight, F. H. (1934a). The nature of economic science in some recent discussion. American Economic Review, 24(2), 225-38.

Knight, F. H. (1934b). Review of the nature and significance of economic science, by Lionel Robbins. International Journal of Ethics, 44(3), 358-61.

Knight, F. H. (1935). Review of institutional economics: Its place in political economy, by J. R. Commons. Columbia Law Review, 35(5), 803-05. 
Knight, F. H. (1936). Pragmatism and social action. International Journal of Ethics, 46(2), $229-36$.

Morgan, M. S., \& Rutherford, M. (1998). American economics: The character of the transformation. In M. S. Morgan \& M. Rutherford (Eds.), From interwar pluralism to postwar neoclassicism (pp. 1-28). Durham, NC: Duke University Press.

Parsons, K. H. (1942). John R. Commons point of view. Journal of Land \& Public Utility Economics, 18(3), 245-66.

Rutherford, M. (2010). Chicago economics and institutionalism. In R. B. Emmett (Ed.), The Elgar companion to the chicago school of economics (pp. 25-39). Cheltenham, UK: Edward Elgar.

Rutherford, M. (2011). The institutional movement in American economics (pp. 1918-1947). Cambridge: Cambridge University Press.

Samuels, W. J. (1977). The Knight-Ayres correspondence: The grounds of knowledge and social action. Journal of Economic Issues, 11(3), 485-525.

Samuels, W. J. (Ed.). (2005). Notes and other materials from Frank H. Knight's course, economics from an institutional standpoint, 1933-1934, research in the history of economic thought and methodology (Vol. 23B, pp. 141-92): Chicago, IL: University of Chicago Press.

Simons, H. C. (1934). A positive program for laissez-faire: Some proposal for a liberal economic policy, in economic policy for a free society (pp. 40-77). Chicago, IL: University of Chicago Press, 1948.

Stabile, D. (1984). Prophets of order: The rise of the new class, technology and socialism in America. Boston, MA: South End Press.

Teggart, R. V. (1932). Thorstein Veblen: A chapter in American economic thought. Berkeley, CA: University of California Press.

Tilman, R. (1992). Thorstein Veblen and his critics, 1891-1963. Princeton, NJ: Princeton University Press.

Tilman, R. (1996). The intellectual legacy of Thorstein Veblen: Unresolved issues. Westport, CT: Greenwood Press.

Vangermeersch, R. G. J. (2005). The life and writings of Stuart Chase (1888-1985): From an accountant's perspective. Amsterdam, NL: Elsevier JAI.

Veblen, T. (1904). The theory of business enterprise. New York, NY: C. Scribner's Sons.

Veblen, T. (1921). The engineers and the price system. New York, NY: Viking Press.

Vining, R. (1939). Suggestions of Keynes in the writings of Veblen. Journal of Political Economy, 47(5), 692-704. 